\title{
Effect of Cytochrome P-450 Monooxygenase Inhibitors on the Rice Tolerance of Azimsulfuron and Bensulfuron-methyl*
}

\author{
Shinichi Shirakura**, Kenji Ito** and Hiroyasu Aizawa**
}

Key words : azimsulfuron, bensulfuronmethyl, cytochrome $\mathrm{P}-450$ monooxygenase inhibitors, rice

キーワード: アジムスルフロン, ベンスルフロンメ チル, チトクローム P-450 依存酸素添加醅素阻害 剤, 水稲

Oxidation by cytochrome $\mathrm{P}-450$ is thought to be one of the important processes for the detoxification of pesticides in plants. The possible involvement of cytochrome $\mathrm{P}-450$ monooxygenases in tolerance of plants to herbicides has been demonstrated through metabolism studies with isolated microsomes from several crops $^{3 \sim 5,8)}$. The use of cytochrome $\mathrm{P}-450$ monooxygenase inhibitors effectively supported the tests to certify that the metabolism catalyzed by $\mathrm{P}-450$ monooxygenases played an important role in herbicide detoxification in plants. ABT (1-aminobenzotriazole) is a suicide substrate for the plant cytochrome $\mathrm{P}-450$ monooxygenase responsible for cinnamate hydroxylation ${ }^{9)}$, and has been utilized to examine the role of cytochrome $\mathrm{P}-450$ monooxygenases in the metab-

* Parts of this study were reported at the 34 th annual meeting of the Weed Science Society of Japan in April, 1995.

** Agricultural Science Laboratory Agricultural Products, Du Pont Kabushiki Kaisha 25-2, 1chome, Kannondai, Tsukuba-shi, Ibaraki 305, Japan.

白倉伸一・伊藤健二・相沢宏保：アジムスルフロン とベンスルフロンメチルの水稲への作用に及ほす チトクローム P-450 依存酸素添加酵素阻害剤の影 響. デュポン(株) 農業科学研究所

(Received March 18, 1995) olism of various herbicides ${ }^{1,6,7)}$. Piperonyl butoxide is a well-known animal cytochrome P-450 monooxygenase inhibitor which synergizes the actions of insecticides, and piperonyl butoxide also synergizes the activity of some herbicides ${ }^{11}$.

$O$-Demethylation at pyrimidine ring is a key process of the metabolism of bensulfuron-methyl (BSM) (methyl $=\alpha-(4,6-$ dimethoxypyrimidin-2-ylcarbamoylsulfamoyl)- $o$-toluate) in rice ${ }^{10}$. Azimsulfuron (1-(4,6-dimethoxypyrimidin-2-yl)-3-[2methyl-4-(2-methyl-2H-tetrazol-5-yl)- $2 H$ pyrazole-3-sulfonyl]-urea) is a sulfonylurea herbicide, and includes dimethoxy pyrimidine ring in its chemical structure, although its metabolic pathway in rice plants has not been explained.

In this paper, the contribution of cytochrome $\mathrm{P}-450$ monooxygenases to the detoxification of BSM and azimsulfuron in rice plants was examined using the two cytochrome P-450 monooxygenase inhibitors, ABT and piperonyl butoxide.

\section{Materials and Methods}

A water solution of BSM, azimsulfuron and the cytochrome $\mathrm{P}-450$ monooxygenase inhibitors, $\mathrm{ABT}$ and piperonyl butoxide, at each concentration including $1 \%$ acetone was prepared. Rice seeds (Oryza sativa L. cv. Nipponbare) were incubated in the dark at $30^{\circ} \mathrm{C}$ for three days to germinate. Six germinated rice seeds sown on a filter paper in a petri dish $(9 \mathrm{~cm}$ in diameter) containing the 
Table 1. Combination effect of BSM/azimsulfuron and cytochrome P450-monooxygenase inhibitors $(\mathrm{ABT} / \mathrm{PB})$ on rice root growth.

\begin{tabular}{c|c|c|l|l|l|l|l}
\hline \multirow{2}{*}{ Herbicide } & \multirow{3}{*}{$(\mathrm{M})$} & \multicolumn{5}{|c}{ Root Length (mm per plant) } \\
\cline { 3 - 8 } & & \multicolumn{3}{|c|}{ ABT (ppm) } & \multicolumn{3}{c}{ PB (ppm) } \\
\cline { 3 - 8 } & & 0 & 5 & 10 & 0 & 10 & \multicolumn{1}{|c}{20} \\
\hline \multirow{2}{*}{ BSM } & 0 & $77 \mathrm{a}$ & $81 \mathrm{a}$ & $64 \mathrm{~b}$ & $77 \mathrm{a}$ & $80 \mathrm{a}$ & $65 \mathrm{~b}$ \\
& $10^{-7}$ & $64 \mathrm{~b}$ & $48 \mathrm{~d}(\mathrm{~s})$ & $48 \mathrm{~d}(\mathrm{~s})$ & $64 \mathrm{~b}$ & $57 \mathrm{c}(\mathrm{s})$ & $49 \mathrm{de}(\mathrm{s})$ \\
& $2 \times 10^{-7}$ & $56 \mathrm{c}$ & $45 \mathrm{~d}(\mathrm{~s})$ & $38 \mathrm{e}(\mathrm{s})$ & $56 \mathrm{~cd}$ & $42 \mathrm{e}(\mathrm{s})$ & $34 \mathrm{f}(\mathrm{s})$ \\
Azimsulfuron & 0 & $77 \mathrm{a}$ & $81 \mathrm{a}$ & $64 \mathrm{~b}$ & $77 \mathrm{a}$ & $80 \mathrm{a}$ & $65 \mathrm{~b}$ \\
& $10^{-7}$ & $62 \mathrm{~b}$ & $53 \mathrm{c}(\mathrm{s})$ & $46 \mathrm{~d}(\mathrm{~s})$ & $62 \mathrm{~b}$ & $50 \mathrm{c}(\mathrm{s})$ & $44 \mathrm{c}(\mathrm{s})$ \\
& $2 \times 10^{-7}$ & $46 \mathrm{~cd}$ & $42 \mathrm{de}(\mathrm{s})$ & $36 \mathrm{e}(\mathrm{s})$ & $46 \mathrm{c}$ & $36 \mathrm{~d}(\mathrm{~s})$ & $32 \mathrm{~d}(\mathrm{~s})$ \\
\hline
\end{tabular}

For each combination, means followed by the same letter are not significantly different at the $5 \%$ level using Duncan's multiple range test.

$(\mathrm{S})=$ Synergistic interaction using Colby's equation

water solution of BSM, azimsulfuron or cytochrome $\mathrm{P}-450$ monooxygenase inhibitors were grown in a growth chamber controlled at $25^{\circ} \mathrm{C}$ and 50,000 lux, with a $12 \mathrm{hr}$ photo period. The petri dishes were covered during the test period to prevent drying. Ten days after sowing, the length of the roots was measured. The means of their length were compared using Duncan's multiple range test for the analysis of variance, and interactions between herbicides and cytochrome $\mathrm{P}-450$ monooxygenase inhibitors were analyzed by the method of Colby ${ }^{2}$.

\section{Results and Discussion}

Table 1 presents the combination effects of BSM or azimsulfuron with the cytochrome P-450 monooxygenase inhibitors. Both herbicides significantly inhibited rice root growth at $10^{-7}$ and $2 \times 10^{-7} \mathrm{M}$. The two cytochrome $\mathrm{P}-450$ monooxygenase inhibitors, ABT and piperonyl butoxide, affected root growth at their highest rates, 10 and $20 \mathrm{ppm}$, respectively. Each herbicide inhibited rice root growth more strongly in combination with ABT or piperonyl butoxide, except for $2 \times 10^{-7} \mathrm{M}$ azimsulfuron with $5 \mathrm{ppm}$ ABT. $\mathrm{ABT}$ and piperonyl butoxide synergized the toxicity of the two sulfonylurea herbicides at every rate tested. Their interactions may result from inhibition of metabolism of the sulfonylurea herbicides in rice plants. This suggests that cytochrome $\mathrm{P}-450$ monooxygenase oxidatively metabolize BSM and azimsulfuron making them inactive in rice plants. Furthermore, $\mathrm{O}$-demethylation of $\mathrm{BSM}$ in rice is probably due to cytochrome $\mathrm{P}-450$ monooxygenases and this process of metabolism may function for azimsulfuron.

Acknowledgment We thank Ms. Haru Yamasaki for her valuable assistance.

\section{References}

1) Cabanne, F., D. Huby, P. Gaillardon, R. Scalla and F. Durst 1987. Effect of the cytochrome $\mathrm{P}-450$ inactivator 1 -aminobenzotriazole on the metabolism of chlortoluron and isoproturon in wheat. Pestic. Biochem. Physiol. 28, 371-380.

2) Colby, S.R. 1967 Calculating synergistic and antagonistic responses of herbicide combinations. Weed Science 15, 20-22.

3) Fonné-Pfister, R., J. Gaudin, K. Kreuz, K. Ramsteiner and E. Ebert 1990. Hydroxylation of primisulfuron by an inducible cytochrome $\mathrm{P}$ 450 dependent monooxygenase system from maize. Pestic. Biochem. Physiol. 43, 232- 
240.

4) Frear, D.S., H.R. Swanson and F.W. Thalacker 1991. Induced microsomal oxidation of diclofop, triasulfuron, chlorsulfuron, and linuron in wheat. Pestic. Biochem. Physiol. 41. 274287.

5) Frear, D.S., H.R. Swanson and F.S. Tanaka 1993. Metabolism of flumetsulam (DE-498) in wheat, corn, and barley. Pestic. Biochem. Physiol. 45 178-192.

6) Gaillardon, P., F. Cabanne, R. Scalla and F. Durst 1985. Effect of mixed function oxidase inhibitors on the toxicity of chlortoluron and isoproturon to wheat, Weed Res. 25, 397-402.

7) Gronwald, J.W. and J.A. Connelly 1991. Effect of monooxygenase inhibitors on bentazon uptake and metabolism in maize cell suspension cultures. Pestic. Biochem. Physiol. 40, 284-294.

8) Moreland, D.E., F.T. Corbin and J.E. McFar- land 1993. Oxidation of multiple substrates by corn shoot microsomes. Pestic. Biochem. Physiol. 47, 206-214.

9) Reichhart, D., A. Simon, F. Durst, J.M. Mathews and P.R. Ortiz de Montellano 1982. Autocatalytic inactivation of plant cytochrome P-450 enzymes: selective inactivation of cinnamic acid 4-hydroxylase from Helianthus tuberosus by 1-aminobenzotriazole. Archives of Biochemistry and Biophysics 216(2), 522-529.

10) Takeda, S., D.L. Erbes, P.B. Sweetser, J.V. Hay and T. Yuyama 1986. Mode of herbicidal and selective action of DPX-F5384 between rice and weeds. Weed Res., Japan 31(2), 157-163.

11) Varsano, R., H.D. Rabinowitch and B. Rubin 1992. Mode of action of piperonyl butoxide as herbicide synergist of atrazine and terbutryn in maize. Pestic. Biochem. Physiol. 44, 174-182. 